\title{
NOTES ON SOME NORTH AMERICAN SNAKES.
}

\author{
BY \\ LEONHARD STEJNEGER, \\ Curator of the Department of Reptiles and Batrachians.
}

Rena humilis B. \& G.

The Museum has recently received from Mr. Herbert Brown, Tucson, Arizona (who on several occasions has favored us with valuable material), four specimens of this worm-snake, making the first record of this rare species from eastern Arizona. They are especially valuable because they show the individual variation both in the position of the eye and the width and shape of the median cephalic series of scales.

We have now specimens from southern California, from Yuma, from Tueson, and from the Cape region of Lower California. Professor Cope has recorded it from Batopilas, Mexico (Proc. Amer. Philos. Soc., XviII, p. 262), though no reference to this locality is found in his Catalogue of Batrachians and Reptiles of Central America and Mexico (Bull. U. S. Nat. Mus., No. 32, 1887).* It also occurs at Colima, on the west coast of Mexico, if I am not mistaken in referring Bocourt's Siagonodon dugesii (Miss. Sc. Mex., Rept., livr. 8, 1882, p. 507, pl. xxıx, fig. 9, pl. xxx, fig. 4 ), as a synomym to the present species. I can find no character in the description, nor in the figures, by which to separate it from $R$. humilis.

\section{Leptotyphlops dulcis (B. \& G.).}

Stenostoma being preoccupied, Leptotyphlops of Fitzinger, the next name in point of date, takes its place, and from this the family will have to be called Leptotyphlopidee instead of Stenostomida, or Stenostoma. tide. Glauconia is two years younger than Leptotyphlops.

A specimen (No. 15534) collected in Cook County, Texas, was recently obtained from Mr. G. H. Ragsdale, which is remarkable for the height of the anterior labial, this shield having the same size and proportions as in the L. albifrons figured by Bocourt (Miss. Sc. Mex., Rept., livr. 8, 1882, pl. xxIx, fig. $10^{\mathrm{a}}$ ), though otherwise quite normal.

In a good series of undoubted $L$. dulcis I find considerable variation in this respect, and the difference is probably of no consequence. This peculiarity, however, led to an examination of the literature and to a comparison of the specimen with Garman's description of Stenostoma

* Op cit., p. 63, Stenostoma dulce is given as from Batopilas. I am unable to say which of the two identifications is the correct one. 
rubellum, from Uvalde, Texas (Rept. Batr. N. Am., I, 1883, Ophid., p. 130). He distinguished it from $L$. dulcis first by the number of scale rows being fourteen and not fifteen, but Cope has already shown the latter number to be erroneous (Proc. Phila. Ac., 1861, p. 305). The next point of difference is the " complete separation of nasals by the rostral," but this is the case in every one of the nine specimens of $L$. dulce ex. amined by me, including the type. The next character relied upon is the number of infralabials, these being five in rubellum and four in dulcis, but here the original description of the latter is again at fault, for in the type I count five infralabials. Finally rubellum is stated to have "only the anterior parietal (i.e., postocular) in contact with the posterior labial," implying that in $L$. dulcis the posterior parietal (i.e., the parietal proper) is also in contact with the posterior labial. So it is also described in the original description, and, moreover, an examination of the type shows that this is the condition of the left side of its face, while on the right side the tiro shields in question are separated by another smaller shield, the normal condition, which is found in all the other specimens. There can, accordingly, be no doubt that S. rubellum is only a synonym of $L$. dulcis.

The occurrence of $L$. dulcis so far north is highly interesting, being the northernmost locality on record, as Cook County adjoins the Indian Territory.

\section{Lampropeltis multistrata KENN.}

A young specimen of this rare species was received through Dr. Timothy E. Wilcox, U. S. Army, from Glover P. Wilcox, who collected it at Fort Niobrara, Nebraska (U. S. Nat. Mus. No. 16108), thus confirming my suspicion that the habitat of the type specimen, as originally given by Kennicott, was correct, viz, Fort Lookout, Nebraska, and that the later substitution of Fort Benton, Montana, rests on an error (see Coues and Yarrow, Bull. U. S. Geol. and Geogr. Surv. Terr., Iv, 1878, p. 284).

This specimen, although agreeing with the type in the more important features, for instance, scale-rows twenty-three, and temporals two and three, differs in many others. Thus the supralabials are seren and not eight, as in the type, and the coloration is still more aberrant, for while in the type the white dorsal interspaces hardly average more than three scale-rows, in the Niobrara specimen they are nearly twice that width; but as the red spots in the latter are rather narrower, the number of white spaces between head and vent is nearly alike, viz, twentyeight in the latter and thirty-one in the type. While in the type, however, the black bordering to the red spots descends as far down as to encroach upon the gastrosteges, in the Niobrara specimen they do not touch the gastrosteges at all; in the latter there is, moreover, a very distinct black postocular black spot covering the lower postoc. ular and the lower temporal, a mark not found in the type. 
Lampropeltis annulata KENN.

Two specimens (17031-17032) recently received from Cameron County, Texas, consequently from near the type locality, bear out fully the characters ascribed to this form as distinguished from $L$. gentilis.

This species has suffered considerably at the hands of herpetologists in spite of the pretty good original description by Kennicott, and the geographical distribution has accordingly been more or less in doubt.

To begin with the catalogue of the specimens in our Museum, pub. lished by Dr. Yarrow (Bull. U. S. Nat. Mus. No. 24, p. 90), two of Kennicott's original specimens, viz: Nos. 1855 (by misprint 1845) and 425, are enumerated under $L$. gentilis, while under $L$. annulata proper No. 1857 (=4293) is the type. The other specimen enumerated under the latter name is no $L$. annulata at all, but a $L$. pyrrhomelas.

Kennicott's type came from Matamoras, Mexico, just across the border, while his second specimen was from the Texan town, Brownsville, just opposite. Cope, in preliminarily mentioning Kennicott's new species enumerated a specimen from Texas. (Pr. Phil. Ac., 1860, p. 257.) In 1875, in his Check List, ete. (Bull. U. S. Nat. Mus. No. 1), on page 36, the habitat of $L$. annulata is given as "Kansas, Arkansas, and Texas," while on page 81 it is stated to be one of the "species confined to the Texan district." Naturally looking for the species (or subspecies) in his "On the Zoological Position of Texas" (Bull. U. S. Nat. Mus. No. 17, 188( ), one is disappointed at finding no reference to it whatsoever. Again, as the type was from Mexican territory, one might expect to find a reference to it in his Catalogue of Batrachians and Reptiles of Central America and Mexico (Bull. U. S. Nat. Mus. No. $32,1887)$, but it is not there, not even among the synonyms.

Under these circumstances it seems advisable to record any addi. tional specimens which might throw light on the geographical distritribution of this form, and to mention that the National Museum, in addition to those already enumerated, possesses a specimen from San Antonio, Bexar County, Texas (No. 7116).

\section{Lampropeltis rhombomaculata (HoLB.).}

Until a very few years ago this snake was considered a southern species confined to the Carolinas and Georgia. In 1888 I myself collected one opposite Georgetown, in the District of Columbia, on the Virginia side of the Potomae (U. S. Nat. Mus., No. 15329), and Dr. A. K. Fisher obtained another near Alexandria, Virgınia, (Cope, Pr. U. S. Nat. Mus., 1888, p. 381). A third (No. 13613) is in the Museum from Virginia probably not far from Washington, Geo. Shoemaker, collector, and a fourth from Dunn-Loring (No. 17444) collected by Mr. Figgins, September 9, 1890. These were all from the Virginia side. In 1889 , however, one was collected by Mr. Charles W. Richmond, at Bladensburg, Md. (No. 17294), and in 1890 two were taken in Brookland, Dis. 
trict of Columbia (No. 16392), by Mr. Holton, and No. 16380 by Prof. W. B. Barrows. During the present year Mr. Audubon Ridgway secured a third specimen in the same suburb of Washington within a few hundred feet of where the others were taken.

\section{Drymobius margaritiferus (SCHL.).}

Schlegel described his Herpetodryas margaritiferus from a specimen in the Paris Museum, "decouvert à la Nouvelle Orléans par M. Barabino." Duméril, however, in the Erpétologie générale, viI, p. 540, says that "L' individu type de l'Herpetodryas perlé, de M. Schlegel, à été adressé de New York par M. Barabino," but adds that since then several other specimens had been received, among them "quatre autres originaires, les uns du Mexique, les antres de la Nouvelle-Orléans." The latest author to report upon the snakes in the Paris Museum, Mr. Bocourt (Miss. Sc. Mex., Zool., Rept., p. 718, 1890) only remarks, "La collection erpétologique du Muséum renferme de nombreux individus de cette espèce: les uns ont été receuillis par M. Barabino dans le sud des Etats-Unis."

As will be seen, the authenticity of the early records of this species having been found within the United States are somewhat defective, and the definitive location of it within our boundaries is therefore very interesting. The proof is furnished by four specimens (U.S. Nat. Mus. Nos. 17069-17072), which were collected in Cameron County, the southwesternmost county of Texas.

\section{Tropidoclonion lineatum (HALLOW.).}

Mr. Julius Hurter has recently discorered this species in St. Louis, Missouri, and presented the Museum with several specimens (1648516487). I found the ground color (which was drab in the living specimens) to vary a great deal in shade, some being lighter, with the dark dots very distinct, others being darker and consequently more uniform.

With regard to the subspecies recently described by Mr. R. Ellsworth Call (Amer. Journ. Se. (3), XLI, April, 1891, p. 298), as T. l. iowae, I can only say that $I$ fail to discover, from his description, any difference which would separate the Iowa specimens from Hallowell's type which came from Kansas, or from those before me from Missouri. In the latter I count nineteen scale rows, the same number as given by Hallowell in the original description, as well as by Mr. Call for his subspecies, although he states that it "differs in the number of rows of dorsal scales."

St. Louis is, with the exception of Urbana, Ill., the most eastern reliable record of this species, for the specimen No. 10089, in Yarrow's catalogue of specimens in the U. S. National Museum (Bull. 24, U. S. Nat. Mus., p. 131), given as T. lineatum is really a Storeria occipitomaculata, and the locality "Hughes, Ohio," for the present species should therefore be eliminated. 
The occurrence of $T$. lineatum in the very city of St. Louis is so interesting that I asked Mr. Hurter for more detailed information, which he kindly furnished in a letter of October 11, 1890, in which he writes as follows :

This snake is only found, to my knowledge, along the river front near the Arsenal grounds in the eity of St. Louis. The place in which it is found covers a space of about three blocks and consists of an abandoned and partly refilled quarry. Here they live among rocks, in the ground and under bushos, feeding on worms and insects, a fact which $\mathrm{I}$ ascertained by examining the contents of their stomachs. They were very common some three years ago, but are now getting scarce owing to the location being utilized for railroad purposes. Having kept specimens in captivity I am able to state that this species is viviparous, one of them bringing forth as many as six young ones.

\section{Coniophanes imperialis (BAIRD).}

Two specimens of this rare snake have recently been collected in Cameron County, Texas (U. S. Nat. Mus., Nos. 17067, 17068).

I have but little hesitation in referring to this species as a synonym Peters' Dromicus clavatus, ${ }^{*}$ for although the reference of the latter to the genus Dromicus implies that the posterior teeth are not grooved, yet the descriptions and figures agree so absolutely with my specimens of $C$. imperialis, in which the posterior teeth are certainly grooved, that I am forced to believe that Peters did not examine the dentition, or, what is more likely, that the posterior teeth had been broken off in the unique example at his disposal. How natural it would be for Peters to refer this species to Dromicus (or rather to Rhadinca, the species of which both Peters and Gïnther refer to Dromicus) when ignorant of its dentition, may be easily understood when one reflects that Cope has repeatedly referred to the present species as "Rhadincea imperialis."

\section{Leptodeira septentrionalis (KenN.).}

An additional specimen (U. S. Nat. Mus. No. 17066) has recently been received from Cameron County, Texas, not far from the locality of the original type. The tail is less than one-fourth the total length; twenty-three seale rows.

*Cope, Bull U. S. Nat. Mus., No. 32, 1887, p. 79, quotes "Dromicus clavatus Günther," with the habitat Guatemala. Is this intended to be the same species ? Peters' specimen came from "Mexico." 


\section{$2 \mathrm{BHL}$ Biodiversity Heritage Library}

Stejneger, L. 1891. "Notes on some North American snakes." Proceedings of the United States National Museum 14(876), 501-505. https://doi.org/10.5479/si.00963801.876.501.

View This Item Online: https://www.biodiversitylibrary.org/item/32426

DOI: https://doi.org/10.5479/si.00963801.876.501

Permalink: https://www.biodiversitylibrary.org/partpdf/11500

\section{Holding Institution}

Smithsonian Libraries

\section{Sponsored by}

Smithsonian

\section{Copyright \& Reuse}

Copyright Status: NOT_IN_COPYRIGHT

This document was created from content at the Biodiversity Heritage Library, the world's largest open access digital library for biodiversity literature and archives. Visit BHL at https://www.biodiversitylibrary.org. 